\title{
Two stage treatment of dairy effluent using immobilized Chlorella pyrenoidosa
}

\author{
Rajasri Yadavalli* and Goutham Rao Venkata Naga Heggers
}

\begin{abstract}
Background: Dairy effluents contains high organic load and unscrupulous discharge of these effluents into aquatic bodies is a matter of serious concern besides deteriorating their water quality. Whilst physico-chemical treatment is the common mode of treatment, immobilized microalgae can be potentially employed to treat high organic content which offer numerous benefits along with waste water treatment.

Methods: A novel low cost two stage treatment was employed for the complete treatment of dairy effluent. The first stage consists of treating the diary effluent in a photobioreactor $(1 \mathrm{~L})$ using immobilized Chlorella pyrenoidosa while the second stage involves a two column sand bed filtration technique.

Results: Whilst $\mathrm{NH}_{4}{ }^{+}-\mathrm{N}$ was completely removed, a $98 \%$ removal of $\mathrm{PO}_{4}{ }^{3-}-\mathrm{P}$ was achieved within $96 \mathrm{~h}$ of two stage purification processes. The filtrate was tested for toxicity and no mortality was observed in the zebra fish which was used as a model at the end of $96 \mathrm{~h}$ bioassay. Moreover, a significant decrease in biological oxygen demand and chemical oxygen demand was achieved by this novel method. Also the biomass separated was tested as a biofertilizer to the rice seeds and a 30\% increase in terms of length of root and shoot was observed after the addition of biomass to the rice plants.

Conclusions: We conclude that the two stage treatment of dairy effluent is highly effective in removal of BOD and COD besides nutrients like nitrates and phosphates. The treatment also helps in discharging treated waste water safely into the receiving water bodies since it is non toxic for aquatic life. Further, the algal biomass separated after first stage of treatment was highly capable of increasing the growth of rice plants because of nitrogen fixation ability of the green alga and offers a great potential as a biofertilizer.
\end{abstract}

Keywords: Dairy effluent, Chlorella pyrenoidosa, Immobilization, Photobioreactor, Sand bed filtration, Nutrient removal, Aquatic life, Biofertilizer

\section{Background}

Agro-food industries like the dairy and brewery sectors produce effluents with high organic load. These effluents contain high BOD, COD and nutrients such as phosphates, ammonia and/or nitrate, pose a serious threat to the water quality and should be appropriately treated before discharging into the environment [1]. There are several physical, chemical and biological methods for the treatment of effluents derived from the agro-food industries. Biological methods are proved to be much eco friendly when compared with other types of treatments [2,3].

\footnotetext{
* Correspondence: p.rajasri@gmail.com

Department of Biotechnology, Sreenidhi Institute of Science and Technology, Hyderabad, Andhra Pradesh 501301, India
}

Research suggests that $\mathrm{N}$ - and P-rich wastewater is also considered as valuable substrate for cultivation of microalgae which is a type of biological treatment [4]. Microalgae are mostly suspension-type microorganisms and efficient solar driven cell factories that can be useful as treating agents for wastewater. The cultivation of algae in wastewaters offers the combined advantages of treating the wastewaters and simultaneously producing algal biomass, which can further be exploited for protein complements and food additives for aquaculture, animal and human feed, energies such as biogas and fuels and biofertilizer [5]. Little information is available on the use of Chlorella pyrenoidosa as a potential agent for treatment of various types of waste waters among the several microalgae used to treat effluents [6].
C Biomed Central

(c) 2013 Yadavalli and Heggers; licensee BioMed Central Ltd. This is an open access article distributed under the terms of the Creative Commons Attribution License (http://creativecommons.org/licenses/by/2.0), which permits unrestricted use, distribution, and reproduction in any medium, provided the original work is properly cited. 
Separation of algal biomass from the treated water discharge is the key for the success of waste water treatment. Numerous efforts have been devoted to developing a suitable technology for harvesting microalgae. The use of industrial filtration and centrifugation is not cost effective for wastewater treatment. In this context, immobilization of algal cells has been proposed for overcoming the harvest problem as well as retaining the high-value algal biomass for further processing [7].

Among all unicellular algal species, Chlorella is a common and effective species for the immobilization and nutrient removal purposes [8]. Uptake rate of phosphorous was low when compared with Nitrogen for Chlorella $s p$ from waste waters $[9,10]$. There are various methods of immobilization out of which calcium alginate is a very simple and cost-effective method, to entrap microbial cells as alginate beads.

Many green algae are also capable of using atmospheric dinitrogen $\left(\mathrm{N}_{2}\right)$ as the source of nitrogen. This important characteristic of nitrogen fixation has enhanced the agro production when green alga is used in agriculture [11]. Many studies have been reported on the use of dried green alga to inoculate soils as a means of aiding fertility. Algalization is the term applied to the use of a defined mixture of algal species to inoculate soil. A $15-20 \%$ increase in rice grain yield was observed because of algalization $[12,13]$.

Reduction of BOD and COD is one of the major challenges in wastewater treatment. If effluent with high BOD is discharged into environment, it will increase the bacterial growth in the water while reducing the dissolved oxygen levels in the water that may prove lethal to aquatic life. Much like BOD, a high COD can also deprive aquatic organisms of oxygen needed for survival [14].

In this study, we made an attempt to treat the diary effluent by a novel, low cost photobioreactor using immobilized
C. pyrenoidosa and evaluate the potential of dairy effluent as a nutrient medium for microalgae growth. The efficacy of sand bed filtration to reduce/remove some of the organic compounds present in the dairy effluent was assessed. The treated dairy effluent is used to check the survival of zebrafish (Danio rario) whose gene sequence is identical with humans to assess the biosafety to aquatic life. In addition, the biomass produced is analyzed for its composition, and amenable to be used as fertilizer.

\section{Materials and methods \\ Microalgae}

Chlorella pyrenoidosa sp. (NCIM NO: 2738) was obtained from National Centre for Industrial Microorganisms (NCIM), Pune, India. Stock culture of Chlorella pyrenoidosa was grown photoautotrophically in BG11 media at $28^{\circ} \mathrm{C}$ under continuous light illumination in four $100 \mathrm{ml}$ borosil flasks. Each liter of the BG11 medium contained $\mathrm{NaNO}_{3}-1.5 \mathrm{~g}, \mathrm{~K}_{2} \mathrm{HPO}_{4}-0.04 \mathrm{~g}, \mathrm{MgSO}_{4}$ • $7 \mathrm{H}_{2} \mathrm{O}-0.075 \mathrm{~g}, \mathrm{CaCl}_{2} \cdot 2 \mathrm{H} 2 \mathrm{O}-0.036$ g, Citricacid-0.006 g, $\mathrm{NaCO}_{3}-0.02$ g, $\mathrm{H}_{3} \mathrm{BO}_{3}-0.00286$ g, $\mathrm{MnCl}_{2} \bullet 4 \mathrm{H}_{2} \mathrm{O}-0.00181 \mathrm{~g}$, $\mathrm{ZnSO}_{4} \cdot 7 \mathrm{H} 2 \mathrm{O}-0.00022 \mathrm{~g}, \mathrm{Na}_{2} \mathrm{MoO}_{4} \bullet 2 \mathrm{H}_{2} \mathrm{O}-0.00039 \mathrm{~g}, \mathrm{CuSO}_{4}$ • $5 \mathrm{H}_{2} \mathrm{O}-0.00008 \mathrm{~g}, \mathrm{Co}\left(\mathrm{NO}_{3}\right)_{2} \cdot 6 \mathrm{H}_{2} \mathrm{O}-0.00005 \mathrm{~g}$, $\left(\mathrm{NH}_{4}\right)_{6} \mathrm{Mo}_{7} \mathrm{O}_{24}$. $4 \mathrm{H}_{2} \mathrm{O}-0.003 \mathrm{~g}, \mathrm{Na}_{2}$ EDTA-0.00001 g. The inoculum was prepared by transferring the cells from stock culture, and incubated aseptically in a $1000 \mathrm{ml}$ flask containing $700 \mathrm{ml}$ of fresh BG11 media under continuous illumination of $34 \mu \mathrm{mol} \mathrm{m} \mathrm{m}^{-2} \mathrm{~s}^{-1}$ at $28^{\circ} \mathrm{C}$ for four days on an orbital shaker set at $120 \mathrm{rpm}$. A 4 day old culture was used as inoculum at $10 \%$ volume for the preparation of immobilized microalgal beads. Gel entrapment is done using $2 \%$ Sodium alginate and $0.1 \mathrm{M}$ Calcium chloride. The average diameter of the algal beads inoculated was $0.556 \mathrm{~m}$. Untreated dairy effluent is collected from Vyshnavi dairy, Khammam, Andhrapradesh, India.

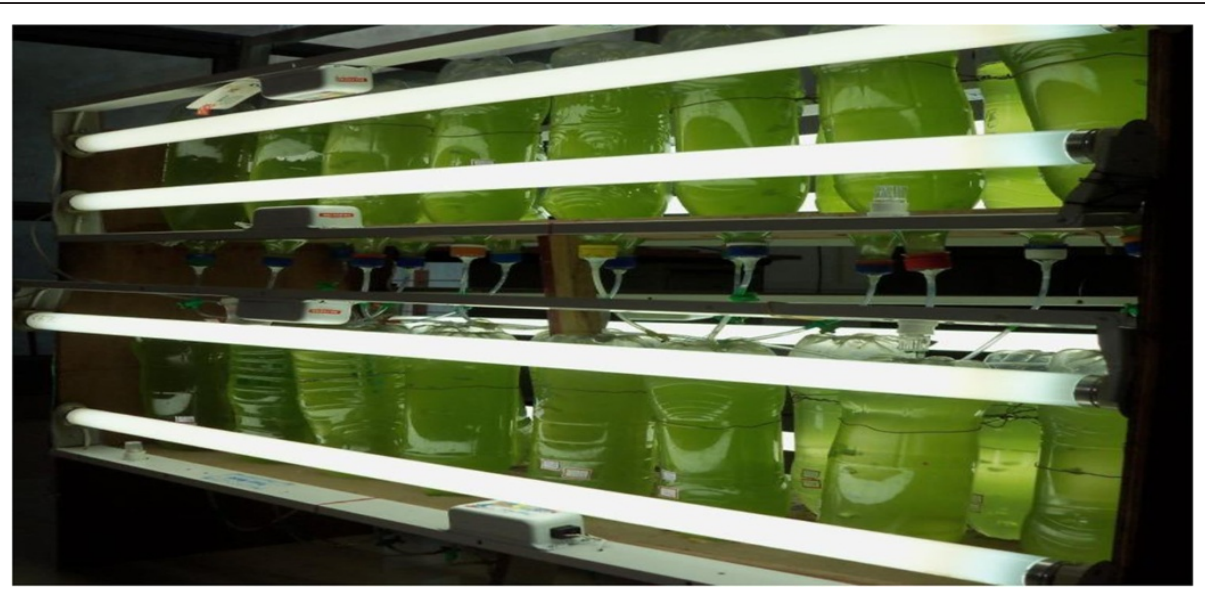

Figure 1 Photo bioreactors with immobilized microalgal beads. Inverted polycarbonate bottles on a wooden rack with immobilized microalgal beads for treatment of dairy effluent. 


\section{Fish collection}

Specimens of zebra fish (4-5 cm long; weight $1.25 \pm 0.25 \mathrm{~g}$ ) were used for toxicity tests. These were procured from a local aquarium shop, Hyderabad were collected from. The fish were transported from the farm in oxygenated polythene bags to the laboratory and immediately transferred into $20 \mathrm{~L}$ capacity containing well -aerated unchlorinated ground water. The fish were allowed to acclimatize for 15 days before the experiments. They were fed with rice bran during the acclimation period. Only healthy and active fishes were used for experiments. The temperature, $\mathrm{pH}$, dissolved oxygen, used for acclimatization were $29^{\circ} \mathrm{C}, 7.2 \pm$ 0.2, 5.0-6.5 $\mathrm{mg} / \mathrm{L}$ respectively.

\section{Photobioreactor}

The immobilized beads are weighed approximately to 50 gm and inoculated in 10 one litre inverted polycarbonate bottles set on a wooden rack (Figure 1). A light intensity

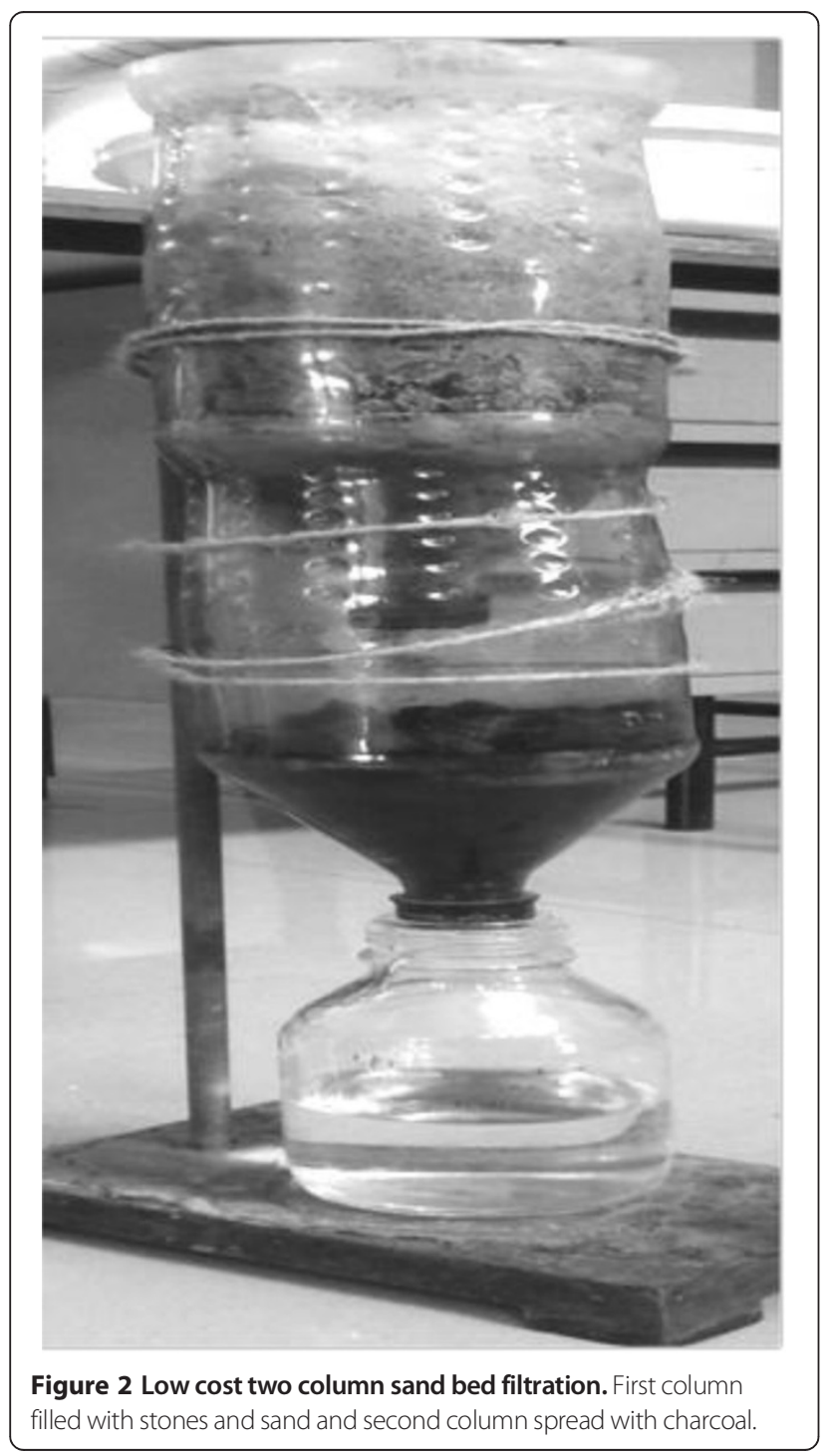

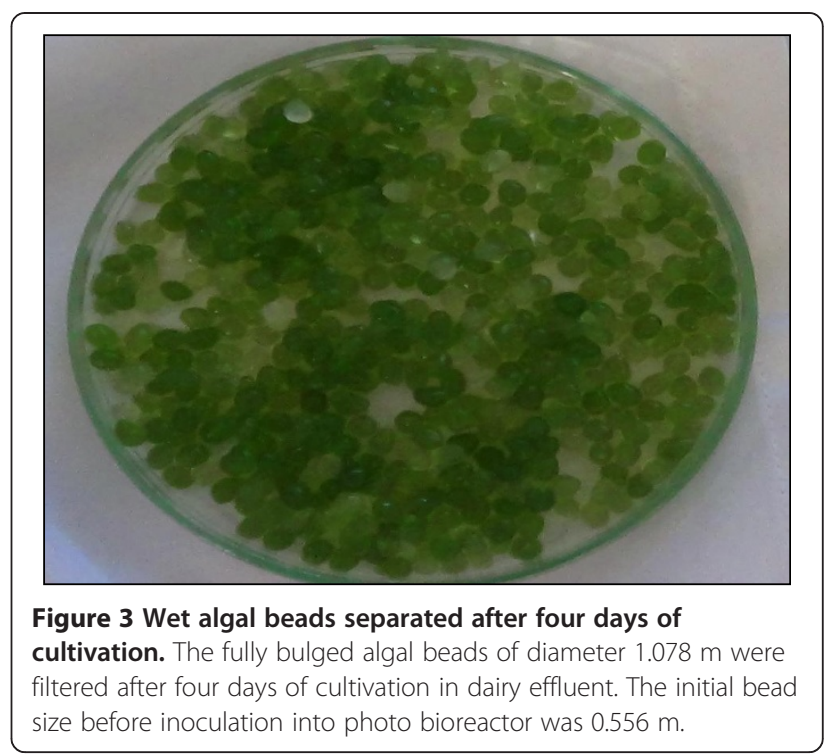

of $55 \mu \mathrm{mol} \mathrm{m} \mathrm{m}^{-2} \mathrm{~s}^{-1}$ was maintained at $28^{\circ} \mathrm{C}$ for four days. Artificial air supply is provided through air pumps at $1 \mathrm{~L} \mathrm{~min}^{-1}$ for all 10 bottles continuously to ensure the suspension of immobilized beads in dairy water and thorough contact of beads with the nutrients present in dairy effluent. The filtered dairy water is analyzed for its biochemical composition.

\section{Sand bed filtration}

A two column sand bed is prepared for the filtration of algal treated dairy water. The first column contains 3 layers of small, medium and large stones each $4 \mathrm{~cm}$ and again each layer is covered by fine sand of about $2 \mathrm{~cm}$ in height (Figure 2). In the second column of sand bed filtration a charcoal bed is spread. The treated water from the first stage slowly drips into the second stage and the treated water will be collected finally into a borosil bottle after passing through charcoal bed. The treated dairy effluent after sand bed filtration was again analyzed and compared with control.

\section{Estimation of lipid, carbohydrate and protein}

The carbohydrate content was analyzed based on the procedure published by Miao and Wu [15]. In short, $0.1 \mathrm{~g}$ dried algal pellet was acidified by adding $20 \mathrm{ml} 2.5 \mathrm{M} \mathrm{HCl}$. The acidified solution was then hydrolyzed at $100^{\circ} \mathrm{C}$ for $30 \mathrm{~min}$ and neutralized to $\mathrm{pH}$ 7. The volume was

Table 1 Algal biomass analysis

\begin{tabular}{lll}
\hline S.No & Biochemical parameter & Percentage \\
\hline 1 & Lipid content & 10.5 \\
2 & Carbohydrate & 28 \\
3 & Protein & 44 \\
\hline
\end{tabular}

The results were an average of three experiments conducted. 
Table 2 Water analysis of three different samples

\begin{tabular}{llllll}
\hline S.No & Parameter & $\begin{array}{l}\text { Control } \\
\text { (untreated dairy effluent) }\end{array}$ & $\begin{array}{l}\text { Dairy effluent after } \\
\text { algal bead treatment }\end{array}$ & $\begin{array}{l}\text { Dairy effluent after } \\
\text { sand bed filtration }\end{array}$ & $\begin{array}{l}\text { Acceptable limits } \\
\text { as per APPCB }\end{array}$ \\
\hline 1 & $\mathrm{BOD}\left(3 @ 27^{\circ} \mathrm{C}\right)$ & $1200 \mathrm{mg} / \mathrm{L}$ & $146 \mathrm{mg} / \mathrm{L}$ & $32 \mathrm{mg} / \mathrm{L}$ & $<100 \mathrm{mg} / \mathrm{L}$ \\
2 & $\mathrm{COD}$ & $2900 \mathrm{mg} / \mathrm{L}$ & $448 \mathrm{mg} / \mathrm{L}$ & $106 \mathrm{mg} / \mathrm{L}$ & $<250 \mathrm{mg} / \mathrm{L}$ \\
3 & $\mathrm{NH}_{4}{ }^{+} \mathrm{N}$ & $35 \mathrm{mg} / \mathrm{L}$ & $0.6 \mathrm{mg} / \mathrm{L}$ & $0.54 \mathrm{mg} / \mathrm{L}$ & $<50 \mathrm{mg} / \mathrm{L}$ \\
4 & $\mathrm{Phosphates}$ & $30 \mathrm{mg} / \mathrm{L}$ & $0.87 \mathrm{mg} / \mathrm{L}$ & $0.39 \mathrm{mg} / \mathrm{L}$ & - \\
5 & $\mathrm{pH}$ & 6.5 & 8.01 & 8.52 & $5.5-9.0$ \\
\hline
\end{tabular}

Sampling and analysis were done as per standard methods prescribed by BIS.

adjusted to $100 \mathrm{ml}$. The filtered sample was subjected to 3,5-dinitrosalicylic acid (DNS) assay [16].

Lipid extraction was performed in a way that was similar to the procedures reported by earlier studies $[17,18]$. Briefly, $1.0 \mathrm{~g}$ dried cells were ground in a mortar and pestle. The dried powder is then transferred to a $50 \mathrm{ml}$ glass centrifuge tube. Chloroform was then added to the tube to make the chloroform/ methanol $(2: 1, \mathrm{v} / \mathrm{v})$. The tube was vortexed for $5 \mathrm{~min}$ and was allowed to stand for $24 \mathrm{~h}$. After that, the tube was centrifuged at 4,000 g for $15 \mathrm{~min}$ to remove the algal solids. The supernatant was collected and the solvent was vaporized using Rotovap at $65^{\circ} \mathrm{C}$. Oil left in the flask without solvent was weighed to calculate lipid content.

Protein estimation is done using Lowry's method [19]. Briefly, $0.1 \mathrm{~g}$ algal powder is taken and $2 \mathrm{ml}$ of $5 \%$ TCA is added. The mixture is centrifuged at $2000 \mathrm{rpm}$ for $10 \mathrm{~min}$. Solution containing pellet is dissolved in $1.5 \mathrm{ml}$ of $0.1 \mathrm{~N} \mathrm{NaOH}$. From the above prepared solution $0.2 \mathrm{ml}$ is taken into $20 \mathrm{ml}$ test tube and $5 \mathrm{ml}$ of alkaline copper solution is added. After incubation at room temperature for $15 \mathrm{~min}, 0.5 \mathrm{ml}$ of Folin-Ciocalten reagent is added. Again the mixture is incubated for $30 \mathrm{~min}$ and OD values were taken at $540 \mathrm{~nm}$.

\section{Results and discussion}

Biochemical analysis of algal biomass

After four days of the growth period the algal beads were separated from the dairy water effluent using nylon filter cloth (Figure 3). Earlier studies mentioned that even at high concentrations (up to $900 \mathrm{mg} / \mathrm{L}$ ) of phosphates, immobilized beads tend to be stable in acidic $\mathrm{pH}$ (5.5-6.5) ranges up to 4 days [20]. Hence the bead stability was maintained throughout the experiment without cell leakage. The fully bulged algal beads of diameter $1.078 \mathrm{~m}$ were analyzed for lipid, carbohydrate and protein content (Table 1). The high protein content of algal biomass was supported by Rodulfo in his earlier studies [21]. The treated water is compared with the control (untreated dairy effluent) after each stage treatment process. A clear liquid without turbidity can be observed after two stage treatment process of dairy effluent.

\section{Dairy water analysis}

Nitrogen and phosphate removal

The phosphates are reduced by $97 \%$ and $99 \%$ after algal bead treatment and sand bed filtration respectively (Table 2). The $\mathrm{NH}_{4}{ }^{+}-\mathrm{N}$ was almost completely reduced after two stage filtration process. There was a significant decrease of $\mathrm{N}$ and $\mathrm{P}$ which may be because of algal uptake and adsorption on alginate gels were found to be the major processes involved in the removal of $\mathrm{N}$ and phosphate in the present study. Previous studies have also reported that air-stripping of ammonia is a possible mechanism for $\mathrm{N}$ removal in an intensively aerated microalgal system with alkaline $\mathrm{pH}$ resulting from photosynthetic activity and aeration [22-24].

\section{Effect on $p H$}

The untreated dairy effluent has an acidic $\mathrm{pH}$ value initially but after algal beads treatment and sand bed filtration the treated effluent is shifted to alkaline $\mathrm{pH}$ range. $\mathrm{NH}_{4}{ }^{+}-\mathrm{N}$ could be lost via ammonia volatilization while $\mathrm{PO}_{4}{ }^{3-}-\mathrm{P}$ was removed by chemical precipitation, because of which alkaline $\mathrm{pH}$ was recorded in the two stage treatment system.

\section{$B O D$ and $C O D$ removal}

Waste water of dairy industry contains large quantities of milk constituents such as casein, lactose, fat, inorganic salts. All these components contribute largely towards their high

Table 3 Relative toxic potential of dairy effluent to Danio rario

\begin{tabular}{lllllll}
\hline S.No & Sample & \multicolumn{2}{l}{ Survival percent } & & \multicolumn{2}{c}{ Toxic potential } \\
\cline { 3 - 5 } & $\mathbf{2 4} \mathbf{h}$ & $\mathbf{4 8} \mathbf{h}$ & $\mathbf{7 2} \mathbf{h}$ & $\mathbf{9 6} \mathbf{~ n}$ & \\
\hline 1 & Untreated Dairy effluent & 0 & 0 & 0 & 0 & Highly Toxic \\
2 & Dairy effluent after algal bead treatment & 100 & 90 & 90 & 90 & Acceptable \\
3 & Dairy effluent after Sand bed filtration & 100 & 100 & 100 & 100 & Non-toxic \\
\hline
\end{tabular}


Table 4 Lengths of root and shoot in rice plant

\begin{tabular}{llll}
\hline S.No & Parameter & $\begin{array}{l}\text { Control } \\
\text { (without biofertilizer) }\end{array}$ & $\begin{array}{l}\text { Test } \\
\text { (with biofertilizer) }\end{array}$ \\
\hline 1 & Root & $2 \mathrm{~cm}$ & $4 \mathrm{~cm}$ \\
2 & Shoot & $10.5 \mathrm{~cm}$ & $15 \mathrm{~cm}$ \\
\hline
\end{tabular}

biochemical oxygen demand. High BOD and COD values lead to the deprival of oxygen for aquatic life in water [25]. BOD and COD have decreased up to $88 \%$ and $85 \%$ respectively after algal bead treatment (Table 2). The same were further reduced by $98 \%$ and $96 \%$ after sand bed filtration which was in acceptable levels prescribed by Andhra Pradesh Pollution Control Board (APPCB), Andhra Pradesh, India. Previous studies also showed that algal uptake had little effect on the removal of COD when compared with that of BOD values which is in agreement with our present study $[26,27]$. Dairy water after algal beads treatment and sand bed filtration each one liter, were used for performing the mortality studies on twenty Danio rario (zebra fish). The results were analyzed in comparison with untreated dairy effluent. It was observed that the mortality was $10 \%$ after first stage of treatment and zebra fish survival percentage increased to $100 \%$ (Table 3) after second stage treatment which proved that the two stage treated water is non toxic to aquatic life.

\section{Algal biomass as biofertilizer}

The algal biomass is also tested for its effectiveness as biofertiliser. A control is taken without adding biofertiliser to the rice seedlings. Another sample is taken with the same number of rice seedlings and 20 gms of dried algal beads were added as biofertilizer. After 10 days of growth the average length of root and shoot were measured and recorded (Table 4).

Green alga can photosynthesize and fix nitrogen, and these abilities, together with great adaptability to various soil types, make them ubiquitous. Ammonia can be taken up by green alga through passive diffusion or as ammonium $\left(\mathrm{NH}_{4}^{+}\right)$by a specific uptake system [11].

\section{Conclusion}

The present study demonstrated that two stage treatment was very effective in removing $\mathrm{NH}_{4}{ }^{+}-\mathrm{N}$ and phosphate from wastewater. A complete removal of $\mathrm{NH}_{4}{ }^{+}-\mathrm{N}(100 \%)$ and $99 \%$ reduction of $\mathrm{PO}_{4}{ }^{3-}-\mathrm{P}$ was achieved within $96 \mathrm{~h}$ of treatment. The completely treated dairy effluent was proved to be non toxic for the zebra fish because of the drastic decrease in BOD and COD values (98\% and 96\% respectively). The algal biomass was higher in protein content $(44 \%)$ and when the same was used as biofertiliser for rice seeds a $35 \%$ increase in growth of the rice plant was observed. Hence the process proved to be useful in treating wastewater for aquatic life and as a biofertiliser.

\section{Competing interests}

The authors declare that they have no competing interests.

\section{Authors' contributions}

YR has contributed for the concept development, design of the study, conduct of experimental work and drafted the manuscript. HG was involved in conducting a part of experimental work. Both authors read and approved the final manuscript.

\section{Authors' information}

YR has done her Masters in Chemical engineering currently holds the position of Associate Professor in Biotechnology and pursuing her Ph.D in the area of algal biofuels. HVNG has completed Graduation in Biotechnology and is working along with YR for his Postgraduate Project work.

\section{Acknowlegements}

The authors thank the Management of Sreenidhi Institute of Science and Technology (SNIST) for their financial support in carrying out this in-house funded project. Special thanks to Vyshanavi DairyPvt Ltd., Khammam, Andhrapradesh, India for providing the dairy effluent for conducting the experiments. The authors also wish to show their gratitude towards Dr. V. Sesha Srinivas, Head department of Biotechnology SNIST, Dr. P. Ravindrababu, Associate Professor, Department of Biotechnology, SNIST and Mr. G. Praveen Kumar for their constant support during the project.

Received: 24 March 2013 Accepted: 4 November 2013

Published: 19 December 2013

\section{References}

1. Mulbry WW, Wilkie AC: Growth of benthic freshwater algae on dairy manures. J Appl Phycol 2001, 13:301-306.

2. Silambarasan T, Vikramathithan M, Dhandapani R, DJ M k, Kalaichelvan PT: Biological treatment of dairy effluent by microalgae. World J Sci Technol 2012, 2(7):132-134.

3. Van-Coillie R, De La Noue J, Thellen C, Pouliot Y: Tertiary domestic wastewater treatment by Scenedesmus sp.Pilot scale culture. Rev Sci Eau 1990, 3(4):441-456

4. Voltolina D, Gómez-Villa H, Correa G: Nitrogen removal and recycling by Scenedesmus obliquus in semicontinuous cultures using artificial wastewater and simulated light and temperature cycle. Bioresour Technol 2005, 96:359-362.

5. Cohen Z: Chemicals from Microalgae. Florida, US: Taylor \& Francis Ltd: CRC Press; 1999.

6. Raposo MFdJ, Oliveira SE, Castro PM, Bandarra NM, Morais RM: On the utilization of microalgae for brewery effluent treatment and possible applications of the produced biomass. J Inst Brew 2010, 116(3):285-292.

7. Nirupama M: Immobilization of Microalgae. In Methods in Biotechnology: Immobilization of Enzymes and Cells. Secondth edition. Edited by Guisan JM. Totowa, New Jersey: Humana Press Inc; 2006:373-391.

8. Robinson PK, Reeve JO, Goulding KH: Kinetics of phosphorus uptake by immobilized Chlorella. Biotechnol Let 1988, 10:17-20.

9. Megharaj M, Peardon HW, Venkateswarlu K: Removal of nitrogen and phosphorus by immobilized cells Chlorella vulgaris and Scenedesmus bijugatus isolated from soil. Enz Microb Technol 1992, 14:656-658.

10. Tam NFY, Lau PS, Wong YS: Wastewater inorganic $N$ and $P$ removal by immobilized Chlorella vulgaris. Wat Sci Technol 1994, 30:369-374.

11. Upasana M, Sunil P: Cyanobacteria: a potential biofertilizer for rice. Resonance 2004, 9(6):6-10.

12. Fogg GE: Nitrogen fixation by photosynthetic organisms. Annu Rev Plant Physiol 1956, 7:51-70.

13. Venkataraman GS: Algal biofertilizers and rice cultivation. New Delhi, India: Today and Tommorrow Printers and Publishers; 1972.

14. Description of commonly considered water quality constituents: Watershed Protection Plan Development Guidebook 0041ppendix B. Georgia; 2001.

15. Miao X, Wu Q: High yield bio-oil production from fast pyrolysis by metabolic controlling of Chlorella protothecoides. J Biotechnol 2004, 110:85-93. 
16. Miao XL, Wu QY, Wu GF, Zhao NM: Sucrose accumulation in salt-stressed cells of agp gene deletion-mutant in cyanobacterium Synechocystis $s p$. PCC 6803. FEMS Microbiol Lett 2003, 218:71-77.

17. Zhu M, Zhou PP, Yu LJ: Extraction of lipids from Mortierella alpina and enrichment of arachidonic acid from the fungal lipids. Bioresour Technol 2002, 84:93-95.

18. Shen Y, Yuan W, Pei Z, Mao E: Culture of microalga Botryococcus in livestock wastewater. Trans ASABE 2008, 51:1395-1400.

19. Lowry O, Rosebrough N, Farr A, Randall R: Protein measurement with the folin phenol reagent. J Biol Chem 1951, 193(1):265-275.

20. Dainty AL, Goulding KH, Robinson PK, Trevan MD: Stability of alginate immobilized algal cells routine cultivation of organism. Biotechnol Bioeng 1986, 28:210-216.

21. Rodulfo BR: Culture and utilization of freshwater algae as protein source. In Proceedings of the Symposium on Culture and Utilization of Algae in Southeast Asia. Tigbauan, Iloilo, Philippines; 1981 [http://hdl.handle.net/ 10862/180]

22. McCarthy JJ, Taylor WR, Taft JL: Nitrogenous nutrition of the plankton in the Chesapeake Bay. I. Nutrient availability and phytoplankton preferences. Limnol Oceanogr 1977, 22:996-1011.

23. Xianhai Z, Danquah M, Zheng C, Potumarthi R, Xiao DC, Lu Y:

NaCS-PDMDAAC immobilized autotrophic cultivation of Chlorella sp. for wastewater nitrogen and phosphate removal. Chem Eng J 2012 187:185-192.

24. Tam NFY, Wong YS: Effect of immobilized microalgal bead concentrations on wastewater nutrient removal. Environ Pollut 2000, 107(1):145-151.

25. Hur J, Lee B-M, Lee T-H, Park D-H: Estimation of biological oxygen demand and chemical oxygen demand for combined sewer systems using synchronous fluorescence spectra. Sensors 2010, 10:2460-2471.

26. Rajasri Y, Rao CS, Ramgopal Rao S, Ravichandra P: Dairy effluent treatment and lipids production by chlorella pyrenoidosa and euglena gracilis: study on open and closed systems. Asia P J Chem Eng. Article In press.

27. Lau PS, Tam NFY, Wong YS: Effect of algal density on nutrient removal from primary settled wastewater. Environ Pollut 1995, 89:59-66.

doi:10.1186/2052-336X-11-36

Cite this article as: Yadavalli and Heggers: Two stage treatment of dairy effluent using immobilized Chlorella pyrenoidosa. Journal of

Environmental Health Sciences \& Engineering 2013 11:36.

\section{Submit your next manuscript to BioMed Central and take full advantage of:}

- Convenient online submission

- Thorough peer review

- No space constraints or color figure charges

- Immediate publication on acceptance

- Inclusion in PubMed, CAS, Scopus and Google Scholar

- Research which is freely available for redistribution 